\title{
The Effect of Educational Intended Trainings by Using Fixing Tool for the Wrist on Some Physical Variables and The Professional Performance Level of Crawling Swimming
}

${ }^{1}$ P. A. Dr. / Nivien Amin Elafifi.

Mohamed Ali Elkot (2005) mentions that swimming is one of the physical activities that is unique and got a special case than the other physical activities and it's the possibility of practicing it by both genders males and females and all different ages and swimming with what it contains of several physical activities is nothing more than a part of many physical activities which aim at growing the new generation a well-balanced upbringing that has several sides. (17:98)

Each of Mustafa Kazem, Abu Elela Abd Elfattah and Osama Rateb (1998) agree on that, swimming is one of the aquatic sports in which the water is a moving facility and that by arms, legs and torso's moves to raise the individuals' efficiency physical, professionally, mentally, psychologically and socially. (22:35)
Despite of the existence of perfect technical performance for swimming methods restricted for each learner in performing this move except of the differences between one learner and another in the functional abilities and so this performance may suit some players and not suit others. (2:62)

Mathaus Dekf (1998) refers to that, each professional performance requires a special kind of abilities that should be available in the player himself in addition to the abilities associated with the training process and the physical and physiological abilities forming basic sides that affecting the numerical accomplishment level and championship attainability as the physical performance require a specific degree of functional preparation that predisposes the body to face the

${ }^{1}$ Assistant Professor at the Aquatic Sports Training Department Faculty of Physical Education - HelwanUniversity Assiut Journal For Sport Science Arts 
requirements related to the practiced activity until the physiological adaptation process occur.(14:152)

\begin{tabular}{lrr}
\multicolumn{1}{c}{ any } & kind & of \\
swimming & is & a \\
combination & of & three
\end{tabular}
factors which are water trainings - practicing training, and that to make swimming so much near to the ideality. (23:153)

Hazem Hassan (2005) refers to that intended trainings / proposed drills are specialized physical trainings aim at improving the physical and professional level of the practiced physical activity. (10:124)

$\begin{array}{rrr}\text { Sara } & \begin{array}{r}\text { Hassan } \\ \text { Elbeh }\end{array} \\ \text { mentions } & \text { that }\end{array}$
swimmers need a plan directed to improving the good technique and that by the watery proposed trainings which distinguished by easily applied and enjoying it practice. (27:49)

Dick Hannula (2001) sees that the biggest problem in the educating and training process in swimming is unfixing the swimmer's performance by training on each part of the skill alone to be perfect in it before moving to another part and the best training types is the components trainings to achieve this purpose. (6:168)

Shams El Din Mohamed (2002) refers to that proposed drills used to improve the professional performance are those which used for the preparation and introduction for learning the moves and skills relative to the different physical activities which used forms of the learned skills forms and its parts, it serves at the first rank the kinetic technique. (28:45)

Ahmed Mahmoud Abd Elhameed (2001) confirmed on the importance of using the proposed drills in learning and correcting the swimmers' faults and improves the professional performance of the swimmers. $(1: 19)$

essential role in practicing all physical activities and being perfect in it, the size of this role and its importance differs according to the type of activity and its nature, it's the extent of the body efficiency in facing the life requirements, power and flexibility are of the most important components of physical fitness as the power training represent an important part in swimming training at 
any age or level, and that by using special exercises and methods, raising the flexibility degree of the swimmer enables him to do the push moves effectively and reduces the resistance amount found by his body in water. (16:186 - 201)

About that Mohamed Ali Elkot (2005) refers to that, the fitness plays an The helping tools represent an important part in the progress of the learning process in the field of learning kinetic skills in swimming as it help in acquiring the move completely and correctly and improving the kinetic skills and achieving a faster rate of learning. (17:106)

The helping tools used in performing the primary swimming training that facilitate learning the skill, as tools make the learner more concentrating on the skills needed to be learned, and it also help to overcome the fear so it's considered of the important pedagogical factors In addition to its role in helping the teacher to vary the tuition this what motivate the learner's tendency to improve his performance to the best. (18:13)

Aly Zaki Mohamed (2002) sees that using the educational techniques in learning the kinetic skills lead to building and improving the kinetic conception of the individual and improve the performance specifications, and affecting the learning rapidity. (3:98)

The researcher sees that, the helping means are of the important factors in attracting the learners attention, motivating their interest and suspense, they work on forming the positive directions in work and improve the performance, save the time and effort of the teacher and help the learner to get the best skill. About this Michel Sidney ,Sylvain Paillette \& Others (2001) refer to that using hands affect positively on the move style and harmony between arms' moves as it also lead to a good understand of the right performance. (15:28)

$$
\text { John Mullen }
$$
confirmed on the importance of using hands/paddles as it help in the correct getting in and the perfect tautening but it may lead to injuring the shoulder from the excess burden. (13:26)

wrist and forearm at the perfect position for swimming it's known as Forearm Fulcrum 
Paddles, it help on improving the efficiency of swimming as it fix the wrist with concentrating on developing the performance, it also designed to complete all paddles' functions by developing the swimming performance for all levels and especially the beginners in swimming or who have performance mistakes, it's formed of two closed divisions surround the first division with the forearm with There are some types of paddles work on fixing each of the hand, entering the hand in the second one, the process of entering the hand through the two closed divisions work on creating an ideal angle for the joints of elbow and wrist during the entry phase, creating this angle leads to correcting the performance of the tool user by teaching the muscles the right position, the swimming experts' advice is using this tool to get in water perfectly. (36)

Havriluk (2005) confirm on that, to improve swimming it's necessary to care with the point of touching the water by hand to perform a correct and efficient tight, the catch stage takes from $23: 30 \mathrm{~cm}$ of the arm circle then pushing by the fingers end to the bottom with raising the elbow high, as if you put your palm and the forearm on a rock and trying to get up. (11:112)

Havriluk (2006) refers to that, stretching the arm to the front then pushing down in the two stages of getting in and holding it causes body rotation around the longitudinal axis, so this rotation affects the swimming technique, pulling deep and strengthen the core system muscles is so important for the rotation and to get a correct and strong pull, so the holding should be in the middle with rotating the shoulders and opening the armpit as if the elbow joint is directing to the front wall with the direction of the other hand to the back and fingers to the bottom, with keeping the elbow joint high in the push stage at angle 90 degree, and to be stretched again at the end of the push.

The right getting in leads to an efficient hold and as the hand gets out from a point in front of the getting in point, some international swimmers their hands preceded the getting out point by a meter in front of getting in point, theses 
swimmers have amazing flexibility in shoulders and back make them put the hand, forearm and elbow in the holding position at a very early stage which make the pull more longer and stronger. (10:218)

Thomas Topolski (2008) referred to that, the swimmer who has good forehand, high affording ability, streamlining body position, good assimilation of the skill and not having a propulsive engine will seem to have a good performance but slow, and here it's necessary to confirm on developing and improving the Early Vertical Forearm (EVE) to reach the best push technique and when photographing under water of the swimmers who got the gold medal we find that most of them perform (EVE) in a good way and each trainer should to concentrate well on the (EVE) trainings, developing it, measuring it and improving it, and it couldn't improve this case without shoulders and core muscles' flexibility, strength and efficiency, and that needs a lot of hours of training on it and could be improved by several exercises with considering to keep on the body's balance and reduce the unnecessary moves. (29:31)

At the end of getting in stage the arm is low at an angle under the water which leads to increase the efficiency, not losing the time and reduce the pressure on the shoulder joint as the position of leaning the arm allow immediately to hold the water, get a faster impulse and saving the lost time to reach this position which increase the pulls rate and that achieved by getting the hand in at an angle of 30 degree and raising the elbow high, when the pull starts at a suitable flection for the elbow joint a higher pull power produced, and let the hand to pass through head on condition that the head be at the right position when feeling the water level at the hairline and when the side and bottom found together at the sight, the hand be in front of the shoulder and see it passing below the head.

Rod Havriluk (2012) sees that, the reason of a bad swimming refluxes to an ineffective breathing move as excess in the heart move deform the body position and increase the resistance and slow the swimming speed, the perfection of breathing process 
makes great difference in performance, and improving the breathing position requires an optimal head position to direct the body to a perfect direction and adjust the position of the rest of the body parts with a light curve at the end of the back to raise the legs and show the heel on the roof, and legs fixity behind the bole without lowering it makes the resistance at its minimum level, and when passing the hand of breathing arm below the hand we get ready to rotate the head and it rotate in the pushing stage, with appearing one eye above the surface and the water surface is in the visual field.(26:30)

John Mullen (2011) confirmed on that, when stretching the arm in the returning stage (Straight arm recovery) it's necessary to fold the hand wrist to not getting the brachium, the forearm and the hand together at the same time which causes water crashing, forearm redness and swimming slowness and obstruction, folding the elbow occurs in the High elbow recovery the hand and the forearm are at a straight line and rotating the shoulder and the hand is ready to hold as the elbow is up and the hand is deeper to improve the tight distance, rotating the shoulders towards the bottom of the bath help in an early reach for (EVE) stage and increase holding the water and the impulse.(13:26)

The scientist Montgomery (2008) advised to wear paws only from the middle finger jockstrap and not wearing the wrist jockstrap as the paws slither if the elbow lowered. (21:30)

Through the researcher's work as a professor assistant at the Aquatic Sports Training Department she found that some girls students have a problem in the paddles moves by taking the wrong position for the arm in the entry stage and consequently they couldn't hold the water in a right way or pulling nor pushing the water effectively as they have been learning crawling swimming at the first year and improving the performance, fixing the faults and being perfect in this swimming at the second year and the researcher found an extremely difficulty in fixing this defect after explaining the right position more than once and seeing the students the right position by the 
explicative devices of shows and photos and after the trainings of improving performance with its different forms.

After the researcher saw the modern scientific references and the information network she found a tool called Forearm Fulcrum Paddles, it works on the constancy of the wrist joint (hand and forearm) at the optimal position to get in the water and hold the pull and push the water by hand and forearm together not with the hand itself, and according to the researcher's knowledge there is no study aims to recognize the effect of proposed trainings by using the tool of fixing the wrist over the physical and professional level of crawling swimming, which made the researcher to do this research hoping to reach a scientific solution for this problem and to benefit from that in learning processes and training on crawling swimming.

\section{Research Goals:}

1) The research aims to recognize the effect of using fixing tool for the wrist on some physical variables and the professional performance level of crawling swimming and that through measuring:

2- Some physical
variables (muscular power of the arms - shoulder joint flexibility - the fist's strength) of the girls student at the second year of the faculty of Physical Education for girls Helwan University.

\section{3- Professional}

performance level (the technical performance for swimming 25 meters crawling time of 25 meters crawling average rate of reciprocations average length of the hit) of crawling swimming of the girls student at the second year of the faculty of Physical Education for girls Helwan University

\section{Study Assumptions:}

- There are differences statistically significance between averages of pre and post measure at the level of some physical variables and the professional performance level of crawling swimming of the girls student at the second year of the faculty of Physical Education for girls Helwan University, the experimental research group.

- There are differences statistically significance between averages of pre and 
post measure at the level of some physical variables and the professional performance level of crawling swimming of the girls student at the second year of the faculty of Physical Education for girls Helwan University, the controller research group.

- There are differences statistically significance between averages of the two post measure of the girls student at the second year of the faculty of Physical Education for girls Helwan University, the experimental and controller research group at the level of some physical variables and the professional performance level for the behalf of the experimental group.

Plan and Research Procedures:

The researcher used the experimental curriculum by designing two groups (experimental - controller) for the pre and post measures for its suitability for the research nature.

*Measuring *Rest meter strip

*Goniometer *Stop watch

*Medical scale *Educational

*Dynamometer swimming pool

\section{Research Sample:}

The sample was chosen by the intentional way from the girls students of the Faculty of Physical Education for Girls in Cairo for the academic year 2012 - 2013 and they are the students who have a problem in arms moves represented in faults at the getting in water stage, inability to catch the water correctly or the inefficiency of the pull and push stages, they were (32) students, and (8) students taken randomly to make the reconnaissance study and finding the scientific interactions, the rest of them were divided into two equal groups one of them experimental applied on it he proposed trainings by using the tool of fixing the hand wrist and the other controller applied on it the traditional style each one of them was (12) students.

\section{Tools and means of collecting} data:

First: Used tools and measuring device:s

Goniomete Dynamometer

Medical Rest meter

scale

Stop watch Educational

Measuring swimming pool

strip 
Second: the Used Tests in the Research:

The researcher made a reconnaissance on the experts who their named showed in attachment (1) about the most suitable physical and professional tests to measure the research variables by the reconnaissance form related to the most suitable tests and putting the suggested program of using proposed trainings away attachment (3)

A: Physical Tests Used in the Research:

- Goniometer to measure the flexibility of shoulder joint.

- Dynamometer to measure the fist's strength in kilogram.

- The test of folding the arms to show the muscular power of the arm (for females).

B: Professional Tests Used in the Research: attachment (2)

- Technical performance degree of $25 \mathrm{~m}$ of (10) degrees.

- Technical performance degree of arms moves in swimming $25 \mathrm{~m}$ crawling of (10) degrees.

Time of $25 \mathrm{~m}$ arms crawling swimming.

- $\quad$ No. of arms' pulls in 25 $\mathrm{m}$ arms crawling.

- Average stroke rate (arms moves) in crawling swimming), by the time of swimming (25) $\mathrm{m}$ crawling/ no. of arms hits for the same distance (second/cycle) the divided by (60)/ cycle time the result is (cycle/minute).

- Average stroke length (arms moves) in crawling swimming, by calculating the distance which is $\mid(25) \mathrm{m} / \mathrm{no}$. of arms hits in (25) meters swimming.

The suggested program of proposed trainings by using a tool for fixing the hand wrist:-

\section{The Suggested Educational Program}

The suggested program by using a tool for fixing the hand wrist aims to improve the level of some physical variables and the professional performance level of crawling swimming of the female students at the Faculty of Physical Education, Helwan University.

Basics of $\begin{aligned} & \text { building the } \\ & \text { educational }\end{aligned}$
puggested

- Considering the variety in performing the exercises and using the fixing hand wrist tool in the training unit to make the students not feeling of boring.

- Following the two principles of graduation from

Assiut Journal For Sport Science Arts 
easy to hard and from simple to complex.

- Taking the previous studies results as a guide when putting the program.

The time distribution of the suggested educational unit:
* The physical preparation (warm-up) (15) minutes.

* Crawling swimming on the back (30) minutes.

* Training by using the helping tool (35) minutes

* Relaxation and finishing (10) minutes

Schedule (1)

The differences statistically significance between the pre and post measure at the level of some physical and professional variables of the experimental group $\mathrm{N}=12$

\begin{tabular}{|c|c|c|c|c|c|c|c|c|c|}
\hline \multirow{2}{*}{$\begin{array}{l}\text { Physical } \\
\text { and } \\
\text { professio } \\
\text { nal tests }\end{array}$} & \multirow[t]{2}{*}{$\begin{array}{c}\text { Meas } \\
\text { uring } \\
\text { unit }\end{array}$} & \multicolumn{2}{|c|}{$\begin{array}{c}\text { Pre } \\
\text { measu } \\
\text { re }\end{array}$} & \multicolumn{2}{|c|}{$\begin{array}{c}\text { Post } \\
\text { measu } \\
\text { re }\end{array}$} & \multirow{2}{*}{$\begin{array}{c}\text { Differ } \\
\text { ences } \\
\text { betwe } \\
\text { en } \\
\text { averag } \\
\text { es }\end{array}$} & \multirow{2}{*}{$\begin{array}{l}\text { Imp } \\
\text { rove } \\
\text { men } \\
\text { t } \\
\text { rate }\end{array}$} & \multirow[t]{2}{*}{$\begin{array}{c}(\mathrm{t}) \\
\text { val } \\
\text { ue }\end{array}$} & \multirow{2}{*}{$\begin{array}{l}\text { Statist } \\
\text { ical } \\
\text { signifi } \\
\text { cance }\end{array}$} \\
\hline & & $\begin{array}{l}\text { devi } \\
\text { atio } \\
\mathrm{n}\end{array}$ & $\begin{array}{l}\text { av } \\
\text { era } \\
\text { ge }\end{array}$ & $\begin{array}{c}\text { devi } \\
\text { atio } \\
\text { n }\end{array}$ & $\begin{array}{l}\text { av } \\
\text { era } \\
\text { ge }\end{array}$ & & & & \\
\hline $\begin{array}{l}\text { Time of } \\
25 \text { meter } \\
\text { crawling }\end{array}$ & $\begin{array}{l}\text { Seco } \\
\text { nd }\end{array}$ & $\begin{array}{l}34 . \\
50\end{array}$ & $\begin{array}{l}1 . \\
25\end{array}$ & $\begin{array}{c}29 . \\
18\end{array}$ & $\begin{array}{l}0 . \\
25\end{array}$ & 5.32 & $\begin{array}{c}18.23 \\
\%\end{array}$ & 3.78 & $\begin{array}{l}\text { signifi } \\
\text { cance }\end{array}$ \\
\hline $\begin{array}{l}\text { Technical } \\
\text { performa } \\
\text { nce } \\
\text { degree of } \\
25 \mathrm{~m} \\
\text { crawling }\end{array}$ & $\begin{array}{r}\text { Degr } \\
\text { ee }\end{array}$ & $\begin{array}{c}6.4 \\
5\end{array}$ & $\begin{array}{l}0 . \\
66\end{array}$ & $\begin{array}{c}8.1 \\
5\end{array}$ & $\begin{array}{l}0 . \\
15\end{array}$ & 1.70 & $\begin{array}{c}26.35 \\
\%\end{array}$ & 4.11 & $\begin{array}{l}\text { signifi } \\
\text { cance }\end{array}$ \\
\hline $\begin{array}{l}\text { Time of } \\
25 \quad \mathrm{~m} \\
\text { arms } \\
\text { crawling }\end{array}$ & $\begin{array}{r}\text { Seco } \\
\text { nd }\end{array}$ & $\begin{array}{l}42 . \\
20\end{array}$ & $\begin{array}{c}1 . \\
15\end{array}$ & $\begin{array}{l}38 . \\
60\end{array}$ & $\begin{array}{l}1 . \\
14\end{array}$ & 3.60 & $\begin{array}{c}9.32 \\
\%\end{array}$ & 3.61 & $\begin{array}{l}\text { signifi } \\
\text { cance }\end{array}$ \\
\hline
\end{tabular}

Follow Schedule (1)

The differences statistically significance between the pre and post measure at the level of some physical and professional variables of the experimental group $\mathrm{N}=12$

\begin{tabular}{|c|c|c|c|c|c|c|c|}
\hline Physical & Meas & Pre & Post & Differ & $\operatorname{Imp}$ & (t) & Statist \\
\hline \multicolumn{5}{|c|}{ Assiut Journal For Sport Science Arts } & & & \\
\hline
\end{tabular}




\begin{tabular}{|c|c|c|c|c|c|c|c|c|c|}
\hline \multirow{2}{*}{$\begin{array}{c}\text { and } \\
\text { professio } \\
\text { nal tests }\end{array}$} & \multirow[t]{2}{*}{$\begin{array}{l}\text { uring } \\
\text { unit }\end{array}$} & \multicolumn{2}{|c|}{$\begin{array}{c}\text { measu } \\
\text { re }\end{array}$} & \multicolumn{2}{|c|}{$\begin{array}{c}\text { measu } \\
\text { re }\end{array}$} & \multirow{2}{*}{$\begin{array}{c}\text { ences } \\
\text { betwe } \\
\text { en } \\
\text { averag } \\
\text { es }\end{array}$} & \multirow{2}{*}{$\begin{array}{c}\text { rove } \\
\text { men } \\
\mathbf{t} \\
\text { rate }\end{array}$} & \multirow[t]{2}{*}{$\begin{array}{l}\text { val } \\
\text { ue }\end{array}$} & \multirow{2}{*}{$\begin{array}{c}\text { ical } \\
\text { signifi } \\
\text { cance }\end{array}$} \\
\hline & & $\begin{array}{c}\text { devi } \\
\text { atio } \\
\text { n }\end{array}$ & $\begin{array}{l}\text { av } \\
\text { era } \\
\text { ge }\end{array}$ & $\begin{array}{l}\text { devi } \\
\text { atio } \\
n\end{array}$ & $\begin{array}{l}\text { av } \\
\text { era } \\
\text { ge }\end{array}$ & & & & \\
\hline $\begin{array}{l}\text { Time of } \\
25 \quad \mathrm{~m} \\
\text { arms } \\
\text { crawling }\end{array}$ & $\begin{array}{r}\text { Seco } \\
\text { nd }\end{array}$ & $\overline{5.81}$ & 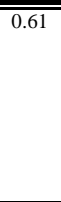 & 7.19 & $\bar{~} 0.13$ & 1.38 & $23.75 \%$ & 3.81 & $\begin{array}{l}\text { signifi } \\
\text { cance }\end{array}$ \\
\hline $\begin{array}{l}\text { No. of } \\
25 \mathrm{~m} \\
\text { crawling } \\
\text { pulls }\end{array}$ & $\begin{array}{r}\text { Num } \\
\text { ber }\end{array}$ & 48.15 & 1.58 & 53.85 & 1.17 & 5.75 & $11.83 \%$ & 3.62 & $\begin{array}{l}\text { signifi } \\
\text { cance }\end{array}$ \\
\hline $\begin{array}{l}\text { Pull } \\
\text { length }\end{array}$ & Meter & 0.53 & 0.01 & 0.59 & 0.12 & 0.06 & $11.32 \%$ & 3.14 & $\begin{array}{l}\text { signifi } \\
\text { cance }\end{array}$ \\
\hline Pulls rate & $\mathrm{S} / \mathrm{n}$ & 68.96 & 0.16 & 84.50 & 0.13 & 15.69 & $22.80 \%$ & 3.65 & $\begin{array}{r}\text { signifi } \\
\text { cance }\end{array}$ \\
\hline $\begin{array}{l}\text { Muscular } \\
\text { power of } \\
\text { arms }\end{array}$ & $\begin{array}{r}\text { Num } \\
\text { ber }\end{array}$ & 12.90 & 1.01 & 15.70 & 0.17 & 2.80 & $21.70 \%$ & 3.47 & $\begin{array}{l}\text { signifi } \\
\text { cance }\end{array}$ \\
\hline $\begin{array}{l}\text { Right fist } \\
\text { power }\end{array}$ & $\mathrm{Kg}$ & 33.65 & 1.24 & 37.94 & 1.12 & 4.29 & $12.74 \%$ & 3.61 & $\begin{array}{r}\text { signifi } \\
\text { cance }\end{array}$ \\
\hline $\begin{array}{l}\text { Left fist } \\
\text { power }\end{array}$ & $\mathrm{Kg}$ & 32.20 & 1.36 & 37.71 & 1.15 & 5.54 & $17.20 \%$ & 3.21 & $\begin{array}{l}\text { signifi } \\
\text { cance }\end{array}$ \\
\hline $\begin{array}{l}\text { Shoulder } \\
\text { joint } \\
\text { flexibility }\end{array}$ & $\mathrm{Ce}$ & 42.11 & 1.92 & 51.17 & 1.11 & 9.06 & $21.51 \%$ & 3.14 & $\begin{array}{l}\text { signifi } \\
\text { cance }\end{array}$ \\
\hline
\end{tabular}

(t) scheduled value at the significance level $(0.05)=$ 1.782

* It's shown from schedule no. (1) that there are there are differences statistically significance between averages of pre and post measure at the level of some physical and professional variables for the behalf of the experimental research group as $(\mathrm{t})$ calculated value was between (3.14 to 4.11) and it is greater than (t) calculated value at the 
significance level (0.05) and for the behalf of post meas * ure.

\section{Schedule (2)}

The differences statistically significance between the pre and post measure at the level of some physical and professional variables of the controller group $\mathrm{N}=12$

\begin{tabular}{|c|c|c|c|c|c|c|c|c|c|}
\hline \multirow{2}{*}{$\begin{array}{l}\text { Physic } \\
\text { al and } \\
\text { profess } \\
\text { ional } \\
\text { tests }\end{array}$} & \multirow{2}{*}{$\begin{array}{l}\text { Mea } \\
\text { suri } \\
\text { ng } \\
\text { unit }\end{array}$} & \multicolumn{2}{|c|}{$\begin{array}{l}\text { Pre } \\
\text { measure }\end{array}$} & \multicolumn{2}{|c|}{$\begin{array}{l}\text { Post } \\
\text { measure }\end{array}$} & \multirow{2}{*}{$\begin{array}{l}\text { Diffe } \\
\text { renc } \\
\text { es } \\
\text { betw } \\
\text { een } \\
\text { aver } \\
\text { ages }\end{array}$} & \multirow{2}{*}{$\begin{array}{l}\text { Im } \\
\text { pro } \\
\text { ve } \\
\text { me } \\
\text { nt } \\
\text { rat } \\
\text { e }\end{array}$} & \multirow{2}{*}{$\begin{array}{l}(\mathrm{t}) \\
\text { val } \\
\text { ue }\end{array}$} & \multirow{2}{*}{$\begin{array}{l}\text { Statisti } \\
\text { cal } \\
\text { signific } \\
\text { ance }\end{array}$} \\
\hline & & $\begin{array}{l}\text { devi } \\
\text { ation }\end{array}$ & $\begin{array}{r}\text { ave } \\
\text { rag } \\
\text { e }\end{array}$ & $\begin{array}{r}\text { dev } \\
\text { iati } \\
\text { on }\end{array}$ & $\begin{array}{r}\text { ave } \\
\text { rag } \\
\text { e }\end{array}$ & & & & \\
\hline $\begin{array}{l}\text { Time of } \\
25 \text { meter } \\
\text { crawling }\end{array}$ & $\begin{array}{c}\text { Seco } \\
\text { nd }\end{array}$ & 34.71 & 1.22 & 30.96 & 0.98 & 3.75 & $\underset{\%}{12.11}$ & 2.99 & $\begin{array}{l}\text { signific } \\
\text { ance }\end{array}$ \\
\hline $\begin{array}{c}\text { Technica } \\
1 \\
\text { performa } \\
\text { nce } \\
\text { degree of } \\
25 \mathrm{~m} \\
\text { crawling }\end{array}$ & $\begin{array}{c}\text { Degr } \\
\text { ee }\end{array}$ & 6.43 & 0.54 & 6.80 & 0.22 & 0.37 & $5.75 \%$ & 2.57 & $\begin{array}{l}\text { signific } \\
\text { ance }\end{array}$ \\
\hline $\begin{array}{c}\text { Time of } \\
25 \mathrm{~m} \\
\text { arms } \\
\text { crawling }\end{array}$ & $\begin{array}{l}\text { Seco } \\
\text { nd }\end{array}$ & 42.10 & 0.47 & 40.17 & 1.65 & 1.93 & $4.80 \%$ & 2.92 & $\begin{array}{c}\text { signific } \\
\text { ance }\end{array}$ \\
\hline $\begin{array}{c}\text { Time of } \\
25 \mathrm{~m} \\
\text { arms } \\
\text { crawling }\end{array}$ & $\begin{array}{c}\text { Seco } \\
\text { nd }\end{array}$ & 5.75 & 0.36 & 5.99 & 0.24 & 0.24 & $4.17 \%$ & 2.32 & $\begin{array}{l}\text { signific } \\
\text { ance }\end{array}$ \\
\hline $\begin{array}{c}\text { No. of } \\
25 \mathrm{~m} \\
\text { crawlin } \\
\text { g pulls }\end{array}$ & $\begin{array}{l}\text { Num } \\
\text { ber }\end{array}$ & 48.10 & 1.18 & 51.22 & 1.47 & 3.12 & $6.48 \%$ & 3.10 & $\begin{array}{l}\text { signific } \\
\text { ance }\end{array}$ \\
\hline
\end{tabular}

Follow Schedule (2)

The differences statistically significance between the pre and post measure at the level of some physical and professional variables of the controller group $\mathrm{N}=12$ 


\begin{tabular}{|c|c|c|c|c|c|c|c|c|c|}
\hline \multirow{2}{*}{$\begin{array}{l}\text { Physic } \\
\text { al and } \\
\text { profess } \\
\text { ional } \\
\text { tests }\end{array}$} & \multirow{2}{*}{$\begin{array}{l}\text { Mea } \\
\text { suri } \\
\text { ng } \\
\text { unit }\end{array}$} & \multicolumn{2}{|c|}{$\begin{array}{l}\text { Pre } \\
\text { measure }\end{array}$} & \multicolumn{2}{|c|}{$\begin{array}{l}\text { Post } \\
\text { measure }\end{array}$} & \multirow{2}{*}{$\begin{array}{l}\text { Diffe } \\
\text { renc } \\
\text { es } \\
\text { betw } \\
\text { een } \\
\text { aver } \\
\text { ages }\end{array}$} & \multirow{2}{*}{$\begin{array}{l}\text { Im } \\
\text { pro } \\
\text { ve } \\
\text { me } \\
\text { nt } \\
\text { rat } \\
\text { e }\end{array}$} & \multirow{2}{*}{$\begin{array}{l}\text { (t) } \\
\text { val } \\
\text { ue }\end{array}$} & \multirow{2}{*}{$\begin{array}{l}\text { Statisti } \\
\text { cal } \\
\text { signific } \\
\text { ance }\end{array}$} \\
\hline & & $\begin{array}{r}\text { devi } \\
\text { ation }\end{array}$ & $\begin{array}{r}\text { ave } \\
\text { rag } \\
\text { e }\end{array}$ & $\begin{array}{r}\text { dev } \\
\text { iati } \\
\text { on }\end{array}$ & $\begin{array}{r}\text { ave } \\
\text { rag } \\
\text { e }\end{array}$ & & & & \\
\hline $\begin{array}{l}\text { Pull } \\
\text { length }\end{array}$ & $\begin{array}{c}\text { Mete } \\
\mathrm{r}\end{array}$ & 0.51 & 0.06 & 0.48 & 0.11 & 0.03 & $\begin{array}{c}6.25 \\
\%\end{array}$ & 2.57 & $\begin{array}{l}\text { signific } \\
\text { ance }\end{array}$ \\
\hline $\begin{array}{l}\text { Pulls } \\
\text { rate }\end{array}$ & $\mathrm{S} / \mathrm{n}$ & 68.81 & 0.14 & 75.00 & 1.15 & 6.19 & $\begin{array}{c}8.25 \\
\%\end{array}$ & 2.47 & $\begin{array}{c}\text { signific } \\
\text { ance }\end{array}$ \\
\hline $\begin{array}{c}\text { Muscula } \\
\text { r power } \\
\text { of arms }\end{array}$ & $\begin{array}{c}\text { Num } \\
\text { ber }\end{array}$ & 12.65 & 1.02 & 13.70 & 0.41 & 1.05 & $\begin{array}{c}8.30 \\
\%\end{array}$ & 2.98 & $\begin{array}{l}\text { signific } \\
\text { ance }\end{array}$ \\
\hline $\begin{array}{l}\text { Right } \\
\text { fist } \\
\text { power }\end{array}$ & $\mathrm{Kg}$ & 33.40 & 0.69 & 34.20 & 1.32 & 0.80 & $\begin{array}{c}2.39 \\
\%\end{array}$ & 2.47 & $\begin{array}{l}\text { signific } \\
\text { ance }\end{array}$ \\
\hline $\begin{array}{c}\text { Left } \\
\text { fist } \\
\text { power }\end{array}$ & $\mathrm{Kg}$ & 32.15 & 0.94 & 34.60 & 1.25 & 2.45 & $\begin{array}{c}7.62 \\
\%\end{array}$ & 2.65 & $\begin{array}{l}\text { signific } \\
\text { ance }\end{array}$ \\
\hline $\begin{array}{l}\text { Should } \\
\text { er joint } \\
\text { flexibili } \\
\text { ty }\end{array}$ & $\mathrm{Ce}$ & 42.71 & 0.49 & 45.60 & 1.65 & 2.89 & $\begin{array}{c}6.76 \\
\%\end{array}$ & 2.87 & $\begin{array}{l}\text { signific } \\
\text { ance }\end{array}$ \\
\hline
\end{tabular}

(t) scheduled value at the significance level $(0.05)=$ 1.782

* It's shown from schedule no. (2) that there are there are differences statistically significance between averages of pre and post measure at the level of some physical and

Schedule (3)

The differences statistically significance between the two post measure of the experimental and controller group at the level of some physical and professional variables under search $\mathrm{N}=12$

Assiut Journal For Sport Science Arts professional variables for the behalf of the experimental controller group as (t) calculated value was between (2.32 to 3.10)) and it is greater than $(\mathrm{t})$ calculated value at the significance level (0.05) and for the behalf of post measure.

\section{(1)}




\begin{tabular}{|c|c|c|c|c|c|c|c|}
\hline \multirow{2}{*}{$\begin{array}{l}\text { Physical } \\
\text { and } \\
\text { professional } \\
\text { tests }\end{array}$} & \multirow{2}{*}{$\begin{array}{l}\text { Measuring } \\
\text { unit }\end{array}$} & \multicolumn{2}{|c|}{ Experimental group } & \multicolumn{2}{|c|}{ Controller group } & \multirow{2}{*}{$\begin{array}{l}\text { (t) } \\
\text { value }\end{array}$} & \multirow{2}{*}{$\begin{array}{l}\text { Statistical } \\
\text { significance }\end{array}$} \\
\hline & & deviation & average & deviation & average & & \\
\hline $\begin{array}{l}\text { Time of } 25 \\
\text { meter } \\
\text { crawling }\end{array}$ & Second & 29.18 & 0.25 & 30.96 & 0.98 & 3.71 & significance \\
\hline $\begin{array}{l}\text { Technical } \\
\text { performance } \\
\text { degree of } \\
25 \mathrm{~m} \\
\text { crawling }\end{array}$ & Degree & 8.15 & 0.15 & 6.80 & 0.22 & 3.65 & significance \\
\hline $\begin{array}{l}\text { Time of } 25 \\
\mathrm{~m} \quad \text { arms } \\
\text { crawling }\end{array}$ & Second & 38.60 & 1.14 & 40.17 & 1.65 & 3.15 & significance \\
\hline $\begin{array}{l}\text { Time of } 25 \\
\mathrm{~m} \quad \text { arms } \\
\text { crawling }\end{array}$ & Second & 7.19 & 0.13 & 5.99 & 0.24 & 3.65 & significance \\
\hline $\begin{array}{l}\text { No. of } 25 \mathrm{~m} \\
\text { crawling } \\
\text { pulls }\end{array}$ & Number & 53.85 & 1.17 & 51.22 & 1.47 & 3.47 & significance \\
\hline Pull length & Meter & 0.59 & 0.12 & 0.48 & 0.11 & 3.21 & significance \\
\hline Pulls rate & $\mathrm{S} / \mathrm{n}$ & 84.50 & 0.13 & 75.00 & 1.15 & 3.84 & significance \\
\hline $\begin{array}{l}\text { Muscular } \\
\text { power of } \\
\text { arms }\end{array}$ & Number & 15.70 & 0.17 & 13.70 & 0.41 & 3.14 & significance \\
\hline $\begin{array}{ll}\begin{array}{l}\text { Right } \\
\text { power }\end{array} & \text { fist } \\
\end{array}$ & $\mathrm{Kg}$ & 37.94 & 1.12 & 34.20 & 1.32 & 3.54 & significance \\
\hline $\begin{array}{ll}\text { Left } & \text { fist } \\
\text { power } & \end{array}$ & $\mathrm{Kg}$ & 37.71 & 1.15 & 34.60 & 1.25 & 3.25 & significance \\
\hline $\begin{array}{l}\text { Shoulder } \\
\text { joint } \\
\text { flexibility }\end{array}$ & $\mathrm{Ce}$ & 51.17 & 1.11 & 45.60 & 1.65 & 3.74 & significance \\
\hline
\end{tabular}

(t) Scheduled value at the significance level $(0.05)=$ 1.711

*It's shown from schedule no. (3) that there are there are differences statistically significance between averages of two post measure of the experimental and controller groups at the level of some physical and professional variables as (t) calculated value was between (3.15 to 3.84) and it is greater than $(\mathrm{t})$ calculated value at the significance level (0.05) and for the behalf of the experimental measure.

Second: Discussing the Results:

- It's shown from schedule no. (1)and shape No(1) that there are there are differences statistically significance between averages of pre and post measure at the level of some physical and professional 
variables for the behalf of the experimental research group as (t) calculated value was between (3.14 to 4.11) and it is greater than $(\mathrm{t})$ calculated value at the significance level (0.05) and for the behalf of post measure.

The researcher refluxes this improvement to using the tool of fixing hand wrist used inside the educational units on the female students of the experimental group as this tool helps in learning the Early Vertical Forearm (pulling stage) which leads to a correct pull by using the entire forearm in pulling water, and developing the muscles memory to understand and keep the (EVE) by thoroughness the hand, wrist and forearm in the optimal position, as it also not allow the wrist joint to change the correct angle, and help on the pull beginning (entering stage) in a high elbow position which lead to improve the swimming efficiency and keeping on the pull power and its streamlining from the beginning to the end, and helps in concentrating on developing the swimming and it is made of durable plastic by the shape that suits the arm shape padded with soft rubber for the comfort of the hand wrist and arm when using it, it also used in the four swimming for the comfort of the shoulder's joint and it was designed opened to reach the optimal position and not causing resistance on the arm.

About this Osama Kamel Rateb (1999) refers to that recourse with the specific helping tools in swimming leads to building and improving the kinetic conception of the learners which works on improving the performance aspects and affecting on the speed of learning, which confirmed on that the technical helping tools used inside water contribute in raising the swimmer efficiency and guarantee full functional fulfillment.

The researcher see that stretching the arm to the front then push down in the two stages of getting in and hold causes rotating the body around the longitudinal axis so that rotation affects the swimming technique, pull depth and exercises of strengthen the core part muscles is important to make the rotation and to get a strong correct pull so the hold should be in the middle with rotating 
the shoulders and opening the underarm as if the elbow joint is directed to the front wall, with the other hand direction backward and the fingers down, with keeping the elbow high in the pushing stage at angle 90 degree, and stretching it again at the end of pushing.

Marc Evans (2011) refers to that it's from the basic principles in swimming is to limit the moves that reduce the impulse with being careful on saving energy and excess effort to raise the speed and overcome the water resistance, and we should keep the body position balanced, streamlining and narrow to reach a high float level, and the interest started finally with some swimmers by getting the Early Vertical Forearm and it should interest in improving that position and trained on it to save the energy and increase the push forward. (43)

The result of this study agree with the study of each of Bahgat Abu Tamea (2007)(3), Hazem Hassan Mahmoud (2005)(4), Shams Eldin Mohamed (2002)(7), Doha Fathy (2011)(8) that to use the proposed training and helping tools in learning swimming has a positive influence in improving the professional performance and physical performance of the swimmers. So that, the first assumption is achieved which states on that, there are differences statistically significance between averages of pre and post measure at the level of some physical variables and the professional performance level of crawling swimming of the girls student at the second year of the faculty of Physical Education for girls Helwan University, the experimental research group.

It's shown from schedule no. (2)and shape no(2) that there are there are differences statistically significance between averages of pre and post measure at the level of some physical and professional variables for the behalf of the controller research group as $(\mathrm{t})$ calculated value was between (2.32 to 3.10) and it is greater than $(\mathrm{t})$ calculated value at the significance level (0.05) and for the behalf of post measure. The researcher refluxes the progress in the professional performance level under search of the controller group for using a group of various trainings inside water that has competitive nature and being Assiut Journal For Sport Science Arts 
suitable for this stage which motivated the students motives toward the practicing for learning and for keeping on and committing to the stated duties on them and the consequent evaluation for them in addition to the motivation toward passing the applied test at the end of the year with noticing the researcher their inability to fix the performance defects and reach their perfection level.

Essam Abd Elkhalek refers to that, the first stage of sport practice directed in it the motives toward satisfying the need to activity and move, the kinetic learning, and showing the ability of the practitioners to do more moves to improve the self and unique on his consorts. (8:55)

Each of Aly Zaki Mohamed (1998) and Mohamed Ahmed Abd Allah (2001) add that, the performance of the students the basic skills and repeating it in a various way and changed whatever with floating tools or without motivating the students senses to perform which make them able to perform in water at a regular dynamic way so it become realizing the space in water that moving in it such as distance, directions and also the time of the body moves and performance sequence in a compatible way contribute in improving the professional performance resulted in continuing in swimming. (25:2) (16 :125131)

The researcher see that the various, changed and continuous sports practices that made by the controller group in lectures causes specific nervous effects on its vital systems which work on improving and developing the ability of performance, in addition to the researcher awareness and the assistants and realizing them of the training load concept and its degrees when repeating the physical and professional exercises given to the controller group inside and outside the water (warm up) and continuity and organizing in it more over the competitive nature between the students that this stage distinguished by it (perfection and fixation of the performance and correcting the faults) to show the best levels and ability on the unique performance to prove their abilities on performance had a 
great effect in improving the physical and professional level in the variables under search of the controller group.

there are there are differences statistically significance between averages of two post measure of the experimental and controller groups at the level of some physical and professional variables as $(\mathrm{t})$ calculated value was between (3.15 to 3.84 ) and it is greater than $(\mathrm{t})$ calculated value at the significance level (0.05) and for the behalf of the experimental measure.

So that, the first assumption is achieved which states on that, there are differences statistically significance between averages of pre and post measure at the level of some physical variables and the professional performance level of crawling swimming of the girls student at the second year of the faculty of Physical Education for girls Helwan University, the controller research group.

It's shown from schedule no. (3) and shapo(3) that The researcher refluxes this improvement of the experimental group not the controller because of the proposed training by using the tool of fixing the hand wrist which help in the correct getting in to the water which lead to an efficient hold and performing the two stages of pull and push efficiently and effectively, which help on putting the hand, forearm and the elbow in the hold position at an early stage which require flexibility and power in shoulders and back to make the pull more longer and stronger.

Jim Montgomery and Matchmakers(2008) referred to that, to improve swimming it's necessary to care with point of touching hand to the water to perform a correct and efficient pull, the hold stage takes from 23:30 $\mathrm{cm}$ from the arm cycle and follow that pushing by pressure by fingers ends to the down with raising the elbow high, as if you put the hand and forearm on a rock and trying to go up. (21)

The researcher see that to improve the pull phase it's necessary to keep the high of the elbow joint in the (EVE) which has a great effect on the catch and feeling water to reach a quicker swimming as a result of stronger pushing and better performance and the scientific research seeks to reach modern ways in (EVE) 
trainings as it's not possible to improve this position without flexibility, strength and efficiency of the shoulders and core muscles, and that need long hours of training on it and it could be improved with several exercises with considering to keep the body balance and reduce the unnecessary moves, taking the suitable positions and especially when getting in water to reach a good catch and efficient push and that what the researcher tried to train the students on it through the proposed training by using a tool for fixing the hand wrist under search.

So that, the first assumption is achieved which states on that, here are differences statistically significance between averages of the two post measure of the girls student at the second year of the faculty of Physical Education for girls Helwan University, the experimental and controller research group at the level of some physical variables and the professional performance level for the behalf of the experimental group.

Conclusions:
Under what the researcher reached from the study results she concluded that:-

The proposed trainings by using fixing tool of hand wrist led to improving the professional performance level (Time of 25 meter crawling Technical performance degree of $25 \mathrm{~m}$ crawling - Time of 25 $\mathrm{m}$ arms crawling - Time of 25 $\mathrm{m}$ arms crawling - No. of $25 \mathrm{~m}$ crawling pulls - pull length pull rate) of the second year students of crawling swimming.

- improving some physical variables (power of muscles' power - power of the right fist - power of the left fist - shoulders joint flexibility) of the second year students of crawling swimming.

\section{References:}

\section{1- Ahmed Mahmoud Abd} Elhakem (2001) the effect of using proposed trainings on the result of learning back swimming, unpublished MBA, faculty of physical education, Menoufya University.

2- Ali Zaki Mohamed, Osama Kamel Rateb (1998): swimming training, t6, Knowledge House, Cairo.

3- Ali Zaki Mohamed (2002) swimming 
learning, training, rescuing), Arabic Thinking House, Cairo. 4- Bahgat Abu Tamea (2007): the effect of using floating helping tools on learning some basic skills in swimming for the students of physical education in Palestine technical mechanism "khodory" a scientific published research, success university magazine, tome (21), edition (1), Palestine 2007.

5- Chaw, J. W.HAY, J.C. Wilson, B.D\&Inele (2000):" the impact of training method to wear clothes on the physiological level for swimming chest, back and crawl on the belly ", Journal of sport sciences, Human Kinetics, U.S.A.

6- Dick Hannula , Nort Thornton :(2001) Swim coaching bible human kinetics U.S.A.

7- Doha Fathy (2011): the effect of grade training program to improve the starting distance and the numerical level in crawling swimming on the belly, MBA, faculty of physical education, Tanta University.

8- Esam Eldin Abd Elkhalek (2003): the physical training theories - applications,
Knowledge Institution, Cairo, t11, Alexandria.

\section{9- Essam Mohamed Helmy:} Juniors' Training Strategy, Knowledge Institution, Alexandria 1998.

10- Havriluk, R. (2006). Magnitude of the effect of an instructional intervention on swimming technique and performance. In J. P. VilasBoas, F. Alves, A. Marques (Eds.), Biomechanics and Medicine in Swimming $X$. Portuguese Journal of Sport Sciences, 6(Suppl. 2), 218-220. 11- Havriluk, R. (2005). Performance level differences in swimming: A meta-analysis of passive drag force. Research Quarterly for Exercise and Sport, 76(2), 112-118

\section{2- Hazem Hassan Mahmoud} (2005): the effect of a training program by using the grade exercises on improving the technical performance of Hilly Care skill on the parallels, the scientific magazine of the sportive and physical educational science, the fourth edition, faculty of physical education, Mansoura University.

13- John Mullen Buoyancy means (paws - buoys) and its importance to improve the performance of swimming, Human Quintx Magazine 2011 
14- Matheus . D . K (1998):

Measurement in physical Education ,3 rd edition ,E.B sounders co, pheladelphia, toronto

15- Michel Sidny (2001) ,Sylvain Paillette \& Others Utilities to pool rookies and their applications in junior schools, the International Journal of Sport, London, Britain

\section{6- Mohamed Ahmed Abd} Allah (2001): the effect of training similar to performance by using some technical devices on the numerical level of junior swimmers who crawl on the belly, Unpublished MBA, faculty of physical education for males in Haram, Helwan University.

\section{7- Mohamed Ali Elkot} (2005): physical training strategy in swimming, the Arabic Center for Publishing, Cairo.

\section{8- Mohamed Ali Elkot} (2005): scientific principles of swimming, Zagazeg.I

\section{9- Mohamed Hamdy} Khafaga (2007): the effect of grade trainings program on improving the numerical level of butterfly swimmers, Unpublished MBA, faculty of physical education, Minia University.
20- Mahmoud Gamal |(2007): the effect of a suggested aquatic training program by using special tools on the physical education level related to health, PHD, faculty of physical education, Jordanian University, 2007.

21- Montgomery (2008) Float on the water - and teach beginners tools, techniques Journal of Mathematical Sciences, London

\section{2- Mustafa Kazem} Mokhtar, Abu Elelaa Ahmed Abd Elfatah, Osama Kamel Rateb (1998): swimming from beginning to championship, Arabic Thinking House, Cairo.

23- Neveen Elafify (2004) study at address the effect of water training to improve the streamlining position of the body on the performance level in crawling swimming on the back, Sport is Sciences and arts magazine, twenty first tome, faculty of physical education for females, Helwan University.

24- Osama Kamel Rteb (1999) learning swimming, $t 3$, Cairo, Arabic Thinking House.

\section{5- Ramy Mohamed Hussein} Saber (2007): the effect of an educational program by using the proposed trainings on the level of the professional level 
of juniors of butterfly swimming, MBA, faculty of physical education, Mansoura University.

26--Rod Havriluk (2012) is a sport scientist and the president of Swimming Technology Research. He specializes in swimming technique analysis and instruction. He conducts clinics for swimmers, triathletes and coaches all over the world. He can be contacted at swimmingtechnology.com.

27- Sara Hassan Fouad Elbeh (2003): the effect of trainings of technical trainings on chosen biomechanical variables and the performance level and the performance level in chest swimming.

28- Shams Eldin Mohamed Mahmoud Shams (2002): the effect of using a program for the special proposed trainings on the technical performance level of chest swimming for juniors, Unpublished MBA, faculty of physical education for males in Cairo, Helwan University.

\section{9- Thomas Topolski(2008)} faster swimming with an early vertical forearm in all strokes

\section{0- Waddah Ghanem}

Elsmed, the effect of using a helping floating tool in learning free swimming for beginners, published scientific research, physical education sciences' magazine, Maowsoul University, Iraq 2005.

31- Wesal El Rbady (2010), the effect of an educational program to improve the pollard angle in corrugating chest swimming by using the floating macaronic, published scientific research, Success university magazine, tome (24) edition (3), faculty of physical education, 2010.

32- www.humankinetics.com

33-http://www.amazon.com

34-

www.thornlieswimmingclub.co $\mathrm{m}$

35-

www.STRswimmingtechnolog yresearch (2012)

36- www.trisports.com - 